811.163.41'367

https://doi.org/10.18485/sj.2017.22.1.5

ЈЕЛЕНА Р. ЈОВАНОВИЋ СИМИТ *

Универзитет у Београду

Филолошки факултет
Оригинални научни рад

Примљен: 01. 09. 2016.

Прихваћен: 15. 12. 2016.

\title{
О КОМПОЗИЦИЈИ ТЕКСТА СА ЛИНГВИСТИЧКОГ ГЛЕДИШТА
}

У овом раду ${ }^{1}$ намеравамо повести расправу о ингеренцијама лингвистике у области композиције, и могућностима лингвиста да се баве том проблематиком. По нашем мишљењу, без обзира на став традиционалне науке о језику да је простор њених научних интересовања ограничен искључиво на реченицу и њене делове (в. о томе подробније: Јовановић и Симић 2015), лингвистика је у могућности - својом истраживачком методологијом и својим теоријским апаратом - да у доброј мери допринесе разумевању и објашњавању 'надреченичних' (и нереченичних) појава у језику. Једна од тих појава (поред структурних особености текста у целини) јесте заправо композиција. Теоријски се морају размрсити базични проблеми суштине, еволуцијских зачетака, као и доње границе структурних факата у тексту, а најважнији је - композиција.

Кључне речи: текст, структура, синтакса, хомогенизација, композиција.

\section{1. ПРИСТУП ТЕМИ}

1. У лингвистичким приручницима термин 'композиција' односи се на лексику ${ }^{2}$ и сл., а не на структуру текста. У теорији књижевности под

*jelenajo@bitsyu.net

${ }^{1}$ Овај рад написан је у оквиру пројекта 178014 Динамика структура савременог српског језика, који финансира Министарство за науку и развој Републике Србије.

${ }^{2}$ Симеон 1969 (s. v.): „1. слагање, 2. сложеница, 3. састав, састављеност, начин састављања, нпр. реченице од ријечи или каквог дијела од његових саставних елемената; усп. творба ријечи". 
композицијом се по традицији мисли на „начин на који се различити елементи књижевног дела (догађаји, ликови, ситуације, теме, мотиви) повезују у јединствену уметничку целину” (РКТ s. v.). Језичка грађа и њено слагање у текст у приручницима тога правца једва да се и помиње. Постоје, међутим, истраживања лингвистичко-стилистичког усмерења у којима је у центру пажње како садржај текста (уопште, не само уметничког) тако и његова језичка форма. Делом су приказана у раду Р. Симића (2017 - у шт.), а делом ћемо се њима бавити у овом прилогу. Резултати истраживања Н. С. Валгине (чији је иницијатор и први зачетник заправо О. А. Нечајева) $)^{3}$ од великог су значаја не само за разумевање опште природе текста, већ и за продор у суштину структурних односа у њему.

1.1. Кратак би резиме прегледа њихових истраживања гласио да постоје бар три аспекта, или у начелу три различита нивоа тих односа: синтаксички, суптекстовни, који се етаблирају унутар исказа; композициони би, по томе, чинили највиши ниво организације, и тичу се глобалне раздеобе на параграфе, поглавља итд.; врло је важно утврдити шта чини средњи ниво између два друга, заправо периферна. Ако 'сложена синтаксичка целина', боље ауторкина 'међуфразна целина' (или ФСТР), и сама може, а по суду Валгине и мора, такође имати значаја у композицији, онда се два принципа - принцип параграфирања као више техничка појава ('типографска', како је називају Дикро и Тодоров) укршта са структурно и смисаоно условљеним сегментирањем, на једној страни, а видећемо: и са композицијом, на другој.

1.2. Поменућемо и В. Одинцова (1980: 102). Он за разумевање текста уопште сматра битним „опис и класификацију композиционих типова”; и при томе мисли на опис и типологију „како појединих [прозних] строфа, логичких целина, тако и целих контекста". Не може се тачно разумети на шта аутор све мисли, али у даљем излагању он тврди и следеће: „У општој композиционој прозној строфи (сложеној синтаксичкој целини) неретко се издвајају два композициона плана. На једној страни издваја се уводни део, у којем је формулисана тема, средњи део - развој мисли, теме; и завршетак, закључак, у којем је садржана поента микротеме строфе, подвучена у смисаоном и синтаксичком погледу". То је класични став о композицији текста уопште (РКТ: s. v.). 'Прозна строфа' схватљива је изгледа заправо као пасус или параграф. Параграф се и по нашем мишљењу може сматрати композиционом јединицом која обухвата низ исказа, а и сама је у начелу склопљена по композиционом принципу. Према томе, Одинцов, занемарујући друге моменте, мисли да се организација текста остварује на нивоу композиције, - а по правилима која стоје изнад граматике и синтаксе језика (при чему не прави разлику између 'композиционе прозне строфе' и 'сложене синтаксичке целине'), и у крајњој

${ }^{3}$ в. Јовановић и Симић 2015 (погл. 1.2.2). 
линији усмерена су на постизање конзистенције текста, као структурне, на првом месту, али и као естетске и стилске категорије. Но овим одређењем композицији се приписује и ужи лингвистички смисао који се тиче просте кохезије текста, а тек у другој инстанци и стилски.

1.3. Овакав приступ је сврсисходан у односу на 'линеарну', одн. вањску структуру, јер инсистира на хијерахији и дистрибуцији елемената ('уводни део' итд.). На другој страни он ипак рађа извесне контроверзе, а једна се односи пре свега на проблем језичких и тематских структурних облика: да ли их треба посматрати поставивши их једно према другоме, или је један састојак мање значајан, док је други значајнији. Шта је основица текста: да ли језичка потка или смисаона подлога? Одинцовљев одговор гласи: „За основу ваља узети функцију и смисао, а не... структуре које улазе у текст” (1980: 83). Аутор се на томе месту ограђује од 'синтаксичких' структура, које у организацији параграфа немају примарни значај, а не помиње композицију и неке друге, нпр. текстовне облике у ужем смислу. Нама је ипак стало до односа композиције и 'синтаксичких' структура, на једној страни, као на другој и 'надсинтаксичких' (интерсентенцијалних, натфразних или сл.) - према друга два типа. На први поглед у тим односима влада потпун склад, јер синтаксичке структуре заузимају суптекстовну позицију, док је композиција - стилска категорија без значаја за стуктурне односе. Видећемо, међутим, да је то додуше донекле тачно, али да на тим релацијама влада сложен сплет механизама који по себи сведочи о суптилности и вечитој покретљивости језичке материје. Ако, наиме, узмемо, као што је у полазној расправи и учињено, да нпр. текст има обавезно сегментативну форму, и да су за њега конститутивне апсолутне паузе, да се синтаксичке појаве одигравају између две такве паузе, дакле унутар појединачног текстовног сегмента, а да су параграфирање и више форме окарактерисани груписањем крупнијих целина и дужим периодима ћутања, онда оваква хијерархија заправо задовољава лингвистичке критерије разграничења синтаксе, текстовних облика и композиције. Али ствари не стоје тако просто као што се на први поглед чини.

1.4. Нпр., упутно је указати на схватање А. Белића (2000: 290) о интегративним процесима код поликлаузалних секвенци, дакле код паратаксе и хипотаксе, о њиховом постању и данашњем стању у језику: „У старим епохама индоевропског прајезика - по њему - била је развијена паратакса (и врло ретко хипотакса), иако је несумњиво да је било и међу таквим реченицама унутрашње зависности. - И у нашем језику, и данас, а тако исто и у свима другим индоевропским језицима, може бити зависних реченица необележених неким нарочитим знаком. На пр.:-Може бити, он је ту. - Дува ветар, крие се дрва, мислиш све ће из корена извалити. - Коса им је, ьом би се покрили. - Она врисну, до бога се чује. - Није тешко видети да у првим реченицама зависна реченица замењује објекат, а у осталим - последицу (дакле један додатак за 
начин којим се ближе одређује предикат)". Белић је пропустио да размисли о томе када је људски род почео схватати апстрактне односе и почео се ьима служити, да ли пре или после настанка простих комбинација речи које данашњи човек тумачи као просте адитивне, или експонативне, експланативне, узрочно-последичне и сл. И да ли је и данас свако обавезан да протумачи те односе као такве док нису посебно обележени језичким средствима. Зато је најбоље, као што смо ми учинили у Српској синтакси (Симић и Јовановић 2002б), правим синтаксичким конструкцијама сматрати само оне код којих су односи саставница експлицитно обележени, не упуштајући се у којој мери они погађају саме односе, а колико од њих одступају; а необележене комбинације јединица дефинисати као асинтаксичке, без обзира колико су прозирни или непрозирни, једнозначни или многозначни њихови међусобни односи. Ваља уосталом видети шта све људски ум тумачи као узрочно-последичну везу (Ковачевић 2012), па ћемо схватити суштину синтаксе не искључиво као израз смисла, већ пре свега као језичку категорију која покрива широк дијапазон смисаоних односа, као што је више него јасно да се исти синтаксички смисао може изразити различитим средствима.

2. Б. Милетић (1952: 72; уп. и: Симић 2010: 202), према примерима што их наводи, има донекле сличан прилаз основним јединицама текста као Одинцов, али он минималном сматра 'фразу', и у теоријском одређењу појма 'фразе' од акцента и хијерархије акцената у полилексемским конструкцијама. Он при томе мисли да је акценат пре свега помоћно средство у организацији реченичне структуре, и то тако што синтаксичкој хијерархији одговара хијерархија акцената, који тада имају различит интензитет: „,акценат реченице служи за нијансирање појединих речи већ према њихову значају у реченици, дакле за изражавање синтаксичких односа и емоција". То значи да је тоналитетска структура говора врло значајан фактор ако не уобличења, а онда бар тумачења смисла - фактор јасноће израза.

а) Оно што Милетић назва 'фразом', горе је случајно реченица, али то по њему може бити и мања синтагматска целина: - Читао сам у новинама // о његовим најновијим песмама. - Реченица се дели на две целине, од којих друга има функцију објекта глагола у предикату 'читао сам'. У тој је целини по нашој оцени најјачи акценат на речи 'најновијим'. 'Фразни акценат', или хијерархија акцената међу њеним саставницама, очито има формативну улогу, но не у значењу синтаксичком, већ 'смисаоном' у ширем значењу те речи: синтаксички посматрана, управна је реч 'песмама', док 'смисаоница' 'најновијим' упућује на информативно језгро (Синтаксичка и тоналитетска хијерархија стоје у обрнутој сразмери). Истицањем једних, и потискивањем других речи у позадину обликује се смисао и појачава се јасност говора, јер то представља инструкцију примаоцу при одбиру важнијих појединости од мање важних. При томе тонска хијерархија није директно зависна од синтасичких 
односа. Битно је при томе уочити да тонски врх 'фразе' не чини увек финална реч, већ - чудно је али истинито - често и синтаксички најниже котирана (овде атрибут 'најновијим'; в. подробније: Симић и Јовановић 2002б: I-II).

б) 'Фраза', како видимо, за Милетића је низ синтаксички повезаних речи између којих је успостављена синтаксичка и акценатска хијерархија: помоћу ње се упућује на основни смисао говора. Овде нам ваља додати да се у положају овако схваћене фразе - као тонски аутономне целине одељене паузама - може наћи и појединачна реч или облик ('Не љути се, човече'). То би заправо значило: синтаксичка структура фразе није одлучујући фактор њене прагматичке егзистенције, већ само интонацијски моменат - одељеност говорним паузама. Али на другом крају лествице, унутрашња структура обележена је синтаксичким средствима.

в) У нашем примеру са 'песмама' (релативна) пауза је обележена косим цртама. У првој фрази истакнута је реч 'новинама', и тако се упућује да је основна мисао у конструкцији упућена томе да се о 'најновијим песмама' пише 'у новинама'. По Милетићу, према томе, фраза је језичка јединица ограничена од других форми истога реда паузама (било којега ранга).

3. У донекле сличном значењу као Милетић, термин фраза употребио је познати руски синтаксичар А. М. Пешковски. У својој Руској синтакси у научном осветљењу (1956: 459-461) он ову језичку јединицу дефинише, као и Милетић, са изговорног гледишта: као јединицу ограничену паузама: „Под 'фразом' разумемо... сваки исечак говора од једне паузе до друге, независно од тога из колико је реченица састављен”. Према томе, за Пешковског је фраза свака језичка јединица ограничена и/или одељена од других таквих јединица паузама, без обзира на унутарње прилике: састав и структурна обележја. Овде бисмо могли прекинути дискусију и утврдити да су Милетићево схватање и М. Пешковског идентична. Али у теорији М. Пешковског има неких посебних момената које је он истицао, а који су од великог значаја за науку. Поћи ћемо у њиховом објашњавању редом, од паузе, или пауза.

а) Пешковски, наиме, разликује две врсте пауза: 'формативну' („,соединительная”) и 'сегментацијску' (,разделительная”). Прва се јавља унутар фразе, дели је на подјединице, и може бити замењена везником (Новчић је запрљан, неугледан -> Новчић је запрљан и неугледан. - Пешковски 1956: 443-444), док је друга међуфразна, и није је могуће везником неутралисати. Пауза сегментацијска - изјашњава се Пешковски у једном моменту - постоји увек међу реченицама било где да се нађу и каквога састава и односа да су. На ову га је солуцију свакако навела руска интерпункцијска регулатива, која заправо не одговара изговорном начелу паузирања, као српска ${ }^{4}$, већ је

${ }^{4}$ Исп. о врстама пауза и проблему интерпункције: Симић 1988; Симић 1998. 
пратилац граматичких правила о употреби (зависних) везника. Но овде ваља подсетити да пример који преносимо садржи паузу међу деловима реченице: 'запрљан, неугледан'.

б) Паузе Пешковски, рекосмо, разврстава у две категорије: ,формативне и , сегментацијске'. Своје налазе о формативној паузи илуструје примером: $-Y$ тој соби намештај је био прекривен засторима, завесе (су биле) спуштене. - Она је у основи непостојана: „Пауза између две реченице... лако се може заменити везником $u$, а да се цела конструкција по интонацији и ритму не измени" (Пешковски 1956: 456). Интонацијска измена је јасна, и настаје утирањем паузе помоћу везника 'и' (У тој соби намештај је био прекривен засторима и завесе (су биле) спуштене). Хоће се рећи да у оквиру јединствене исказне форме састављене од више реченица (клауза) - реченице могу бити раздељене паузама које су изостављиве ако се на прелазу постави везник. Но у оба случаја оне чине јединствену фразу. Фраза би по том схватању била јединица између две апсолутне паузе, која унутар себе не мора садржати релативне паузе, али их не искључује.

в) Пешковски је, према томе, на теоријском нивоу превидео важну ствар, коју је на аналитичком плану и саิм констатовао: да и међуреченични (боље међуклаузални) или међулексикални прелаз унутар исказне форме не мора бити обележен паузом, ако је на томе месту употребљен везник. А таква пауза, даље, ипак није факултативна у обичном смислу речи - не може се просто изоставити - већ је заправо 'супститутивна', заменљива везником - јер је изостављива под условом да на њено место дође везник.

г) Додаћемо узгред: изостављивост пауза, уопште узев, није безизузетачна, јер се каткада - под одређеним условима - везник и пауза могу трпети у истој позицији; пауза дакле понекад остаје и поред употребљеног везника. И пример који наводи Пешковски, будући заправо на ивици између оних где је пауза заменљива везником, и трпељива са њим, уз малу измену, тј. употребом везника 'а' уместо 'и', задржава паузу (обележену зарезом), и кад је ту везник: У тоj соби намештај је био прекривен засторима, а завесе (су биле) спуштене. Ако бисмо прихватили да је Милетићева фраза ограничена паузама нижега (формативног) нивоа, а блок, паузама вишег (сегментацијског) типа, онда је његов блок изједначив са исказом (и са 'фразом' А. М. Пешковског). Наш пример и јесте типична исказна структура која није изједначива са појмом реченице, јер обухвата собом више од једне реченичне структуре, клаузе ('намештај је био прекривен' - 'завесе су биле спуштене'). 


\section{2. О КОМПОЗИЦИЈИ СА СТАНОВИШТА ФОРМАТИВНОГ И СЕГМЕНТАЦИЈСКОГ}

1. Врло је битна чињеница да унутарисказна пауза, као и остале паузе тога ранга, не мора бити, и често није апсолутна, већ релативна, и неутралише се, у начелу, помоћу везника. Но ми поменусмо 'и остале паузе тога ранга', па је потребно објаснити ту тврдњу. Наиме, постоје и 'међулексемске' паузе које су у начелу супститутивне са везницима. Такав је почетни пример А. Пешковског: Новчић је запрљан, неугледан -> Новчић је запрљан и неугледан, а додаћемо му још један који нам је тренутно при руци, а који ћемо трансформисати у обрнутом смеру: - Кад се она Швабица и туђа вера петља око Симке, биће нешто горе од женског (ДЋ Кор 190) -> Кад се она Швабица, туђа вера, петља око Симке... - Уклањањем везника изазвали смо појаву паузе између 'Швабица' и 'туђа вера', коју смо обележили зарезом.

а) И управо је за нас важна поука из ове анализе коју, према интенцијама самога Пешковског, стављамо на прво место: да постоји конструктивно начело неутрализацијског паузирања - тј. релативних пауза (Милетић 1952); и битна је такође поука коју стављамо на друго место: да неутрализацијску функцију овде имају речи посебне врсте - везничке речи. Везници, или свезице, како видимо, у начелу су факултативно употребљиви - и синтаксичке форме функционално нису онеспособљене њиховим одсуством, али су донекле ипак друкчије смисаоно и интонацијски уобличене: у одсуству везника, на његовом је месту постављена пауза, и фразне структуре унеколико се осећају не као чланови јединствене смисаоне целине већ као збир делимично осамостаљених, или можда по себи аутономних сегмената.

б) Из другог угла посматране, према томе, из угла употребе везничких речи, фразне се структуре могу дефинисати као конструкције унутар којих се начелно употребљавају везници. Ту управо важи подстицајна Белићева (1998: 97) констатација по којој се везници срећу у три синтаксичке позиције: (a) у напоредним конструкцијама састављеним од речи; (б) у исто таквим секвенцама чији су чланови реченице; и (в) између зависне реченице (клаузе) и управне јединице уз коју стоји.

2. Враћајући се Милетићу, подсетићемо се поново да се његов појам 'фразе' разликује од онога који заступа Пешковски: за Милетића је фраза сегмент који код Пешковског може чинити 'полуфразу', сегмент између било какве две паузе.

2.1. Но релативност пауза о којима говоримо значи да је и 'фраза' релативан појам, и то утолико што није увек једнозначно одредљива синтаксичким обележјима: може обједињавати речи у унутарреченичну синтагматску целину, али може обухватити и реченицу, или више реченица између којих је 
потрта пауза. Сматраћемо управо - ако хоћемо најједноставнијим начином дефинисати фразну структуру - да она представља низ речи међу којима нема паузе. Но одмах се мора додати да је унутар тако схваћене фразе у начелу увек могућа појава паузе посебне врсте - релативне паузе ('формативне': т. 3 , под а), - која је у неким случајевима (али не увек и практично) поништива увођењем везника. Ми паузу, наравно, не сматрамо чисто формалном појавом, али не ни директним изразом синтаксичких, и уопште смисаоних односа међу јединицама говора. Да бисмо разумели целу расправу, морамо се упознати и са једном новом појединошћу која ће донекле изменити став о условној уклоњивости пауза. Наиме, из стилских разлога могуће је у начелу у сваки спој пунозначних речи уметнути паузу, тј. поставити у писаном тексту зарез, и уклонити их. в. нпр. мали исечак из текста М. Црњанског:

И док му се, у души, као у неком бескрајном кругу, једнако понављаху мисли о одласку, о одласку некуд, у Русију, над којом се у очајању, изнемогао, после толико месеци тумарања, $и$ патье, био наднео, дотле му је, заспалом први пут опет код куће, у телу дрхтало, као нека звезда, последње зрно некадање младости...

МЦ Сеобе I: 250.

И при површном разгледању, пример показује да постоје две врсте изостављивих пауза. (1) Једне су уклоњиве без икаквих видних последица: - И док му се, $у$ души, као у неком бескрајном кругу, једнако понављаху мисли... -> И док му се $y$ души, као у неком бескрајном кругу, једнако понављаху мисли... (2) Друге су заменљиве везником: - ...над којом се у очајању, изнемогао, после толико месеци тумарања, и патње, био наднео... -> - ...над којом се у очајању и изнемогао, после толико месеци тумарања, и патње, био наднео... - Једне су стилске, а друге структурне.

2.2. О свему томе - а и о неким додатним моментима - дају се кратке напомене у Правописном приручнику Р. Симића (1998: 97), па преносимо неке од тамошњих напомена и објашњења.

а) „Обличким и прозодијским (ритамско-мелодијским...) средствима 'на једној страни (се) спаја оно што припада заједно, а на другој раздваја оно што заједно не припада' (Б. Милетић)".

б) „Композиција говора заснована је, дакле, на два међусобно супротстављена језичка начела: садржински, смисаоно и облички повезане целине изговарају се континуирано, док на местима где се речи у тим елементима разилазе, настаје изговорни прекид - пауза".

2.3. Паузи се, рекосмо, може приписати синтаксичка релеванција, али не и синтаксичко значење. Она упућује на застој или прекид артикулације као сигнал посебних односа међу јединицама, али није способна да укаже на обележја и категоријалну припадност тих односа - није способна да их означи у правом смислу те речи. Унутарфразне паузе могу бити синтаксички дезакти- 
виране или уметањем везника или без икакве измене у саставу конструкције: а то заправо значи да су делови фразе, или више суседних фраза, кад се нађу у међусобном додиру, начелно спојиви у једну јединствену.

3. Ритамско-мелодијска структура исказа, ипак - као што смо већ напоменули, - није одређена искључиво релативношћу пауза. Паузе које се јављају унутар јединственог исказа, рећи ћемо, нису увек онога типа који дозвољава укидање појавом везника или без њега. Чак се у том погледу јасно разликују паузе које је могуће укинути, и оне које нису изостављиве. У поменутом Правописном приручнику (Симић 1998: 74) наводе се два различита примера из Андрићевих текстова: - Почитељ. На једној нози стоји, једним се стопалом држи земље, и то не цүелим; - Лице, то је извет на тој биљцуи која се зове човек. - Говори се затим о паузи између прве речи и остатка сваког од ових примера. - „У оба случаја издвојена је реч која именује тему. Та могућност извире из осећаја већег конструктивног јединства у остатку описа и супротстављености назива теме њеној анализи”. „Али постоји међу њима и једна важна разлика...: у првом случају, наиме, можемо изоставити сваки интерпункцијски знак, а у другом не". Тамо је реч о интерпункцији. Но како су наша начела постављања интерпункцијских знакова у директној вези са ритамском, а преко ње, у општем смислу, често и са синтаксичком структуром говора, корисно је погледати шта и о томе још пише у правопису.

а) „У другом примеру (дакле) није могуће изоставити интерпункцијски знак: - *Лице то је цвет - није допуштен начин писања. Реч 'то' због нечега (највише стога што њена 'синонимност' са 'лице' подразумева да само једна од двеју речи може једнократно чинити конструкцију са 'је цвет': - Лице је цвет + То је цвет = Лице // то је цвет), - ни облички ни изговорно - не може бити укључена у јединствену конструкцију са 'лице', већ остаје на позицији 'додатог' елемента... Пауза обележена интерпункцијским знаком - обавезна je. То као прво. И друго: она је условљена значењем речи и облицима, који свој нарочит израз имају у начину груписања". - Овде смо суочени са једним новим моментом - са неуклоњивом унутарисказном паузом. Какав је њен однос према фразној структури говора? И како је третирати у парадигматским односима међу паузама? Ми ћемо... у хијерархији пауза разликовати 'потенцијалне', 'реалне релативне','реалне постојане' и 'апсолутне'.

б) „Друкчије је са знаком између речи 'Почитељ' - и потоњих. Ова пауза није обавезна. То је видно из осећаја легитимности структуре настале уклањањем паузе, одн. интерпункцијског знака којим је обележена: - Почитељ на једној нози стоји... Разлика између ове и полазне верзије није у њиховој разумљивости већ у емоционалности” (Симић 1998: 99-100). Но било како да тумачимо наш пример, остаје факат да постоје две врсте релативних пауза. Једне су израз 'става' произвођача исказа ('говорника') и назваћемо их 
стилским, а друге не зависе од његове воље, већ од прилика у самој структури текста - оне су структурне по природи.

в) Прво што пада у очи при разгледању наших примера и њиховог коментара, јесте да су они у ствари двојаки и по постању, а и по природи односа међу сегментима. Први од њих настао је слично ономе што га наводи Блумфилд: - Да, господине; - дакле комбинацијом двају исказа уз уклањање сувишних лексичких јединица, али уз изостанак сваке синтаксичке трансформације којом би било назначено конструктивно јединство нове творевине (Симић и Јовановић 2002б). Други пример може се тумачити као резултат истог процеса, али је при томе структурно активирана конгруенција облика, која доприноси јединству новонастале конструкције.

4. Преформулисаћемо, с тим у вези, поново дефиницију фразне структуре како је схватају Пешковски ${ }^{5}$ и Милетић, уводећи у њу синтаксички параметар о којем смо управо говорили. (а) По првој: фразну структуру чине јединице обједињене глобалном структуром и апсолутним паузама, али унутар те структуре у начелу раздељиве интенционално или структурно, односно синтаксички условљеним релативним паузама, или обележиве (и) везницима. (б) По другој: фразна структура је јединица одељена од осталих у низу паузама било којег ранга, која у себи није раздељена паузама. На крају ћемо додати још један врло битан моменат који помиње Н. С. Валгина. То је чињеница која уосталом проистиче и из наше овдашње расправе, тј. да текст не мора бити схваћен као непокретна структура, већ као корпус елемената код којих се испод површине стално осећају разноврсни смисаони покрети који теже да ставе у покрет и површинске структурне односе (Јовановић 2013a: 177 и д.).

a) Но да се присетимо речи Н. С. Валгине, које на први поглед звуче банално, али у себи носе важну истину: „Делови сложене синтаксичке целине лако се обједињују у сложену реченицу ако уместо тачака поставимо друге ознаке - запете, тачке и зарезе, црту, више тачака". Нису наравно увек у питању интерпункцијски поступци по себи, него кохезиони, одн. дисперзиони процеси, који условљавају промену тонске линије, и дубину паузе. Но овако схваћени као што их Валгина тумачи, и када су такви, поступци интерпунгирања заправо зависе од 'интенције', тј. од ауторове намере да тексту да̂ овакав или онакав изглед. Зато смо их и назвали стилским.

\footnotetext{
${ }^{5}$ Наш појам 'фразе', како је већ горе речено, и поред терминолошког поклапања, није у ближој вези са 'фразном структуром' из терминолошког апарата Н. Чомског (1984: 35. и д.). Чомски говори о 'фразној' или 'конституентској' структури 'деривиране реченице' уколико је ова представљива помоћу 'деривацијског стабла' као хијерархијска структура (нпр. S - NP + VP или сл. - где S заступа појам реченице, а NP и VP субјекатску и предикатску синтагму као реченичне 'конституенте').
} 
б) Валгина овоме додаје и следећу напомену: „Параграф не подлеже таквим експериментима, пошто по природи није синтаксичка појава...”. Сложићемо се са њеним мишљењем уз напомену да параграф, као што је и она сама утврдила, није увек ни надисказна структура, јер се каткада уклињава у његове унутрашње односе и раслојава их у целине по нечему равне параграфима. Такав композицијски поступак познат је нпр. законским, али и научним текстовима.

5. Изостављивост, и обратно: успостављивост пауза - тамо где је могућа - отвара нове видике и на фразне структуре, било да их схватимо по Милетићевом, било по систему појмова А. М. Пешковског. Интересантно је размислити о позицијама успостављивих - изостављивих пауза. Погледајмо и следећи пример:

То је жена увела и усамљена, која се шаље у ватру, само кад, старије, и оштрије, муштерије, дођу и бирају обућу. Јако је осетљива. Улепшава се, фрака, а облачи упадљиво. Носи црвене шешириће. Фарба косу. Увреди се за сваку ситницу. Тражи трубадурску куртоазију. Смешна је.

МЦ Лонд 1: 167

a) Ток излагања је иначе сасвим уобичајен, али је местимично густина зареза повећана изнад нормале коју препоручује српска интепрункцијска норма. У светлу те интерпункције секвенца 'старије, и оштрије' као да добија статус низа апозитива, као да је издвојена из говорног низа и постала накнадно објашњење. Уз то је и сама 'исецкана' у делиће међусобно удаљене паузом: 'старије - и оштрије'. Потенцираном употребом зареза писац је постигао неку врсту 'растреситости' текста, и могућност да антиципацијом речи из низа истакне значај сваке појединости о којој приповеда.

б) Према крају навода поменута 'растреситост' добија на интензитету, и прелази заправо у нови квалитет: смисаоне целине постају самосталне у тој мери да су уобличене у посебне исказне форме. Примећујемо да је оправданост таквог поступка у различитим случајевима различита. Закључна исказна форма заиста смисаоно стоји издвојено, и представља исход излагања. Ни претпоследњем исказу не приличи да буде примакнут осталима на ниво унутарисказне организације, јер искорачује из описа спољашњости дотичне даме и враћа се њеној 'осетљивости' с почетка описа. Остале пак чине нешто као низ у набрајању, и могле би бити графијски организоване и помоћу зареза: - Jaко је осетљива, улепшава се, фрака, а облачи упадљиво, носи ирвене шешириће, фарба косу. Увреди се за сваку ситнииу. Тражи трубадурску куртоазију...

в) Закључујемо да распоред и статус пауза делимично стварно зависе од ауторове интенције. С тим у вези је лако и без даље анализе, а у светлу управо размотреног примера, устврдити да је место успостављивих пауза препознатљиво, и да се налази између сваке две пунозначне речи. При томе је теже раставити чвршће синтагматски повезане речи ('Носи црвене шеши- 
риће'), а лакше оне са лабавијом везом: - То је жена увела и усамьена, која се шаље... -> То је жена, увела и усамљена, која се шаље... // То је жена, увела, $и$ усамљена... - Места на којима смо накнадно додали зарезе заправо су позиције потенцијалних пауза. Потенцијалне су паузе према томе, оне позиције континуираног говора на којима су успостављиве праве паузе, релативне или апсолутне. Текст се може, успостављањем или укидањем пауза тамо где су оне необавезне - по вољи делити на сегменте различитог опсега, а при томе чинити згуснутијим или растреситијим. Интонација је према томе регулатор густине текстовног ткива, а то значи и начина деловања на примаоца, рекосмо горе: јасноће.

\section{3. О ФРАЗИ КАО ГОВОРНОЈ И ТЕКСТОВНОЈ СТРУКТУРИ}

1. Крајњи исход наше дискусије о композицији, и посебно о фразним структурама, и о различитим схватањима Б. Милетића и А. М. Пешковског, биће да је конститутивни моменат фразних структура релативна или потенцијална пауза 6 .

a) Потенцијалне паузе разграничавају носиоце 'акцената', који својом хијерархизованошћу творе интонацијски рељеф фразе. Реалне релативне паузе јесу средство истицања сегмената као носилаца посебних функција. Сваки од сегмената може бити релативно самостално рељефиран, и имати свој тонски и смисаони врхунац (наравно, уколико је структурно комплекснији:? 'То је жена увела и усамьена'; када су 'тема' и 'рема' једночлане: 'то је - жена', дијапазон кретања тона је ужи).

б) Све што рекосмо указује на крајњу еластичност и структурну покретљивост 'фразних' структура. Уместо да супротставимо мишљење А. М. Пешковског и Б. Милетића о вишечланости или једночланости 'фразе', тј. о постојању или непостојању унутарфразних пауза - боље је стога упутити на флотантност 'фразе' и на могућност 'стезања' говорног низа, тј. истискивања пауза из његове структуре, на једној страни, и импостације пауза, као и њиховог појачања до међуисказног нивоа, те о трансформационим могућностима једночланих фразних структура у бисегментне и полисегментне - испарцели-

\footnotetext{
${ }^{6}$ Изузетак је, рекли смо горе, једночлана јединица ограничена апсолутним (или релативним) паузама, коју ми такође сматрамо специфичном фразном структуром.

${ }^{7}$ Разним типовима слова покушавамо упутити на чињеницу двоструке структурираности, и успона тона како је тиме условљен: од почетка према крају тонска линија доживљава постепен успон, али тако да се разазнају две тематско-рематске целине, које на вишем нивоу опет чине некакву тематско-рематску структуру. Целина има обрисе градацијског успона: $\mathrm{x}-x-x-\boldsymbol{x}$.
} 
сане релативним паузама, - као и о њиховој даљој дисперзији у вишеисказне секвенце. И све у обрнутом смеру.

2. Но сем крајње еластичности језичке материје, и релативности наших налаза о јединицама и њиховом понашању - ова анализа показује ипак да је могуће расправљати о говорним јединицама, могу се идентификовати, описати и дефинисати њихови састојци, и утврдити функције тих састојака у вишим структурама. O 'фразној' структури говорићемо као о основици композиционе структуре говора и текста, али и као о основној ћелији у којој је могућа хијерархизација елемената, истицање једних а потискивање других у позадину.

а) Да поновимо: по Пешковскоме и по Милетићу интонација је средство уобличења 'фразе'. Разлика у приступу том проблему ипак је међу њима велика: Милетић мисли да је 'фраза' исечак говора између две паузе, било релативне или апсолутне, са јединственом интонацијском контуром (Милетић у том контексту говори о 'смисаоници', тј. о носиоцу 'акцента' као о преноснику кључног садржаја фразе.); Пешковски пак сматра да су релативне паузе унутарфразна појава, и да је фраза - према томе - језичка јединица ограничена апсолутним паузама. По томе би фраза била идентична са исказном формом. Фраза је средство интонацијског уобличења говора, док је исказна форма, иако у великој мери зависна од фразирања - ипак одредљива као претежно синтаксичка јединица. Овим двема структурама уобличава се смисао говора, као и његов језички изглед.

б) Мисао А. Пешковског о режњевитом изгледу фразе компатибилна је са идејом о тзв. 'актуалној перспективи' и сегментацији конструкција на 'тематски' и 'рематски' елеменат. Сваки од тих елемената, према томе, имао би своју интонацијску контуру, и свој 'акценат', у положају тонске доминанте. Између 'теме' и 'реме' такође постоји хијерархијски однос, па је 'рема', као носилац нове информације, и смисаоно и тонски надређена 'теми'.

3. Сад нам ваља размислити и о општем смислу паузирања, и правој функцији пауза.

a) Ради тога ћемо се још једном вратити неуклоњивим паузама у конструкцијама типа Лице, то је свет... - Потребе говора намећу контакт лексичких или других јединица који није увек савладив обухватањем интонацијским средствима, а ни формалним обележјима у јединствену целину. Обично се мисли да је то један од синтаксичких механизама - апозиција. Но и по терминолошком лику 'апозиција' заправо упућује на асинтаксички тип контакта ${ }^{8}$. Лексеме у додиру - по правилу принуђене деловањем заједничке управне речи (кондензатора: - Кюигу смо назвали 'текстографијом', теоријом

8 Лат. appositus примарно и значи 'оближњи', дакле: који је само у просторној вези са елементом према којем се управља. 
о структури текста - Симић и Јовановић 2002б) - подвргнуте су тонској компресији и одговарајућој деградацији паузе међу њима, али задржавају синтаксичку самосталност једна у односу на другу. Питање је, на крају, где сместити апозицију? Ако је веза међу деловима форме асинтаксичка - куда онда припада? - Нема друге него је сместити у круг композицијских појава, и с тим у вези закључити да композиција са својим асинтаксичким механизмима повремено, услед компресије више исказа у један - сеже у унутарисказни структурни простор, али не као саставни елеменат синтаксичких структура, већ као принудни пратилац њихов, и преклопљен њима.

б) За разлику од наведеног случаја, постоје и они обрнуто конципирани - код којих се тоналитетском декомпресијом синтаксичка структура исказа дистрибуира у више исказних форми. Такви су односи нпр. код 'контекстно условљених' номинација типа: - Како? Шта кажеш? - Ништа ... - Исказна форма Ништа успоставља граматички однос према осталим исказима као да је део конструкције - јер већ и на први поглед примећујемо да је у облику акузатива, као и шта. - Граматички односи су сасвим живи, али су изговорно 'побеђени' сегментацијским паузирањем, и уместо синтаксичке, на плану исказа се јавља текстовна структура. Таквих случајева има довољно у језичкој грађи, а ми ћемо навести један упечатљив исечак из стваралаштва М. Црњанског:

- При том, за тај тили час, док опет не усни, шта све не угледа у полусну! Реку ито под брегом иуми, испунивши сву ноћ. По разливеним водама, у рупама и јаругама, месечине. Трску прозора и крова, са које капье небројено много капьииа, кап по кап. Облаке, што се ковитлају све наниже. Непрегледне врхове врбака, пуне шибља.

... Тада, помућеном свешћу, прво зачује лавеж паса и пој петлова, да одмах затим широм, у мраку, отвори очи и не види ништа, али му се учини као да види, у висини, бескрајан, плави круг. И у њему звезду.

МЦ Сеобе 1: 10.

(1) Није потребно много напора да се чувена визија звезде из Сеоба М. Црњанског у потоњем примеру препозна, као и облик акузатива именице којом се на њу упућује. А облик акузатива мотивисан је управним '(као да) види'. Између објекта и његове управне речи постављен је међуисказни интерпункцијски знак, што напомиње да је овај осамостаљен (изговорно), иако је синтаксички задржао позицију која му припада. Исти статус имају секвенце са акузативом на почетку из претходног дела наведеног случаја: 'реку', 'трску', 'облаке'.

(2) Друкчији је синтаксички положај секвенце По разливеним водама, у рупама и јаругама, месечине. Облик локатива одговара функцији адвербијала за место, који ова има у односу на свој управни глагол '(са које) капље (небројено много капљица)'.

(3) У свим овде анализираним случајевима синтаксичка структура је интонацијски разбијена и разложена на међуисказни ниво - што ће рећи: на ниво композицијске структуре (која овде преклапа синтаксичку). 
4. Све у свему, чисто лингвистичким путем може се, како видимо, утврдити минимални вид (и доња граница) композиције.

a1) Њена је основна ћелија уклопљена у синтаксичке структуре, и препознаје се по неуклоњивој паузи међу јединицама - нпр. међу неким врстама апозиције и сл.

а2) Њен други појавни облик представљају паузе уметнуте међу саставнице синтаксичких конструкција, којима се интонацијски разламају синтаксички јединствене структуре, и унутарисказни односи промовишу као међуисказни.

б) Варијантама поменутих облика могу се сматрати неки даљи случајеви замене синтаксичких облика организације композиционим.

б1) Један од њих заступљен је у случајевима какав је следећия:

Да бисмо правилно одредили минималну стамбену површину, која је полазна тачка за проучавање сваког стамбеног организма, морамо водити рачуна:

- о броју становника у стану,

- о прописима хигијене,

- о економским могућностима.

Б. Несторовић, Стамбене зграде

Три паралелне конструкције које описују предуслове за пројектовање изградње станова организоване су у параграфирану конструкцију, иако су им сачувани унутарисказни синтаксички односи. Композициони принцип и овде је уклињен у тело исказне форме.

б2) Нешто је друкчији вид параграфирања заступљен у следећем примеру:

Према овоме можемо разликовати три основне врсте степеништа у зградама за становање:

1) Општа степеништа (или јавна), која служе како свима становницима зграде тако и свима страним посетиоцима. Она се појављују како у колективним стамбеним зградама тако и у оним са породичним становима где зграда има један или више спратова изнад приземља.

2) Приватна или домаћа степеништа, која се појављују у индивидуалним породичним кућама... За разлику од првих, ова степеништа немају јавни карактер и њихово место у диспозицији основе није везано за улаз и улицу..., јер страни посетиоци обично немају са њима никакве везе.

3) Споредна степеништа ретко долазе у обзир у зградама са породичним становима... У колективним или јавним стамбеним зградама, у већим домовима или хотелима ова су степеништа често потребна било за исту сврху као у породичним индивидуалним кућама, било као помоћна степеништа за случај опасности.

Б. Несторовић, Стамбене зграде

${ }^{9}$ У тексту овог и следећег примера извршене су неке мање правописне и граматичке исправке, али у њихов облик није дирано. 
Конструкција је мешовита по типу, јер прва два сегмента по синтаксичким односима долазе у ред унутарисказних конструкција, док последњи има самосталну организацију. Интерпункцијски су ипак сви изједначени: почињу у новом реду, великим почетним словом, а на крају носе тачку. Оваква организација нема нелегални карактер, али је ипак специфична и налази се на прелазу између унутарисказне и међуисказне.

б3) Други је пример додатно интересантан и по томе што је композицијска схема подржана ознакама екстерног порекла, позајмљена из логичко-математичких система. Такав је следећи случај:

Узроци гласовних смена налазе се најчешће (а) у историјском развоју језика, али и (б) у природи језика уопште.

Симић и Јовановић 2007: 35

У континуирано написану исказну форму која на први поглед нема никаквих симптома композицијске организације - ипак су импостирани ванлингвистички маркери два паралелна адвербијала. И ту се екстерним средствима у организацију умеће композицијски принцип, али на врло специфичан начин.

\section{4. ЗАКЉУЧНЕ НАПОМЕНЕ}

1. Преглед литературе и анализа грађе показали су да се композиција може проучавати како књижевно-теоријски тако и лингвистички. Надреченичне, нереченичне, фразне и исказне структуре важне су за разумевање композиције говора и текста.

2. Организација структурних елемената у тексту може се разматрати синтаксички - дакле, унутар реченице, суптекстовно - тј. онако како се етаблирају унутар исказа, и композиционо - хоћемо рећи интерисказно. У том смислу, 'сложена синтаксичка целина' или 'међуфразна' има значаја у композицији.

а) Фразне структуре могу се хијерархијски разврставати, па сем микрофразе, исечка говора са континуираним изговором ограниченог двема паузама било којег ранга, - постоји комплексна фраза, исечак говора испарцелисан релативним паузама; макрофраза раздељена релативним и постојаним паузама, као и хиперфраза, која унутар своје структуре има и апсолутне паузе.

б) На синтагматском плану хијерархија је успостављива под утицајем опште тонске контуре исказа, али и под интонацијским и смисаоним утицајем парцијалних унутарисказних сегмената у општој структури.

3. Композициони план, на крају - тиче се највишег нивоа организације текста, и његове глобалне раздеобе на параграфе, поглавља и друге веће или 
мање композиционе целине. Принцип параграфирања као више техничка појава ('типографска') укршта се са структурно и смисаоно условљеним сегментирањем, на једној страни, и са композицијом, на другој.

\section{ИЗВОРИ}

Несторовић 1952: Б. Несторовић, Стамбене зграде, Београд: Научна књига.

МЦ Лонд 1 (1974): М. Црњански, Роман о Лондону 1, Београд: Нолит.

МЦ Сеобе I (1978): М. Црњански, Сеобе, Београд: Нолит.

Симић и Јовановић 2007: Р. Симић и Ј. Јовановић, Српска граматика, Београд: НДСЈ и Јасен.

\section{ЛИТЕРАТУРА}

Белић 1998: А. Белић, Општа лингвистика, Изабрана дела I, Београд: Завод за уџбенике.

Белић 2000: А. Белић, Историја српског језика, Изабрана дела IV, Београд: Завод за уџбенике.

Валгина 2003: Н. С. Валгина, Теория текста, Москва: Логос. Цит. по електронском издању: - Янко Слава (Библиотека Fort/Da) // http:// yanko.lib.ru // http://yanko.ru // http://tvtorent.ru

Јовановић 2000: Јелена Јовановић, Три аспекта анализе исказа (Исказне форме у роману Корени Добрице Ћосића), Српски језик V, 641-676, Београд: НДСЈ.

Јовановић 2013а: Јелена Јовановић, Лингвистички и стилистички аспекти проучавања реченице, Београд: Јасен.

Јовановић 2013б: Јелена Јовановић, Језичке студије, Београд: Јасен.

Јовановић Симић 2014: Јелена Јовановић Симић, О жанристици (генологији) као лингвистичкој дисциплини, Филолог, бр. V/2014/9, Бања Лука: Филолошки факултет Универзитета у Бањој Луци.

Јовановић Симић 2015: Јелена Р. Јовановић Симић, 'Жанр' и структура прозног текста, Српски језик XX, 137-155.

Јовановић и Симић 2009: Јелена Јовановић и Радоје Симић, Текст као језичка и комуникацијска структура, Српски језик XIV, Београд, 591-628. 
Јовановић и Симић у шт.: Јелена Јовановић Симић и Радоје Симић, Текстографија.

Јовановић и Симић 2015: Јелена Јовановић Симић и Радоје Симић, Вербатологија (основи науке о вербализачији света), НДСЈ и Јасен.

Јолес 1978: A. Jolles, Jednostavni oblici, Zagreb:

Ковачевић 1998: Милош Ковачевић, Синтакса сложене реченице у српском језику, Београд: Рашка школа; Србиње: Просвјета.

Ковачевић 2012: Милош Ковачевић, Узрочно семантичко поље, Београд: Јасен.

Милетић 1952: Бранко Милетић, Основи фонетике српског језика, Београд.

Нечајева 1999: О. А. Нечаева, Очерки по синтаксической семантике и стилистике функиионально-смысловых типов речи, Улан-Удэ.

Одинцов 1980: Виктор Васильевич Одинцов, Стилистика текста, Москва: Наука.

РКТ 1992: Речник књижевних термина. Београд: Институт за теорију књижевности.

Симеон 1969: R. Simeon, Enciklopedijski rječnik lingvističkih naziva, Zagreb.

Симић 1975a: Радоје Симић, Теоријско-методолошки проблеми у типологији словенске реченице, JФ ХХХІІ, Београд: САНУ.

Симић 1975б: Радоје Симић, Две класичне теорије исказа у језичкој науци новог века, НССВД 4/2, 283-298, Београд.

Симић 1988: Р. Симић, О говорној интонацији, Књижевност и језик, XXXV/3, $165-173$.

Симић 1998: Р. Симић, Општа стилистика, Београд: НДСЈ.

Симић и Јовановић 2002а: Радоје Симић и Јелена Јовановић, Основи теорије функиионалних стилова, Београд: НДСЈ и Јасен.

Симић и Јовановић 2002б: Радоје Симић и Јелена Јовановић, Српска синтакса I-II, Београд: НДСЈ И Јасен.

Симић и Јовановић 2009а: Радоје Симић и Јелена Јовановић, О дискурсу, Узданица - часопис за језик, књижевност, уметност и педагошке науке, $\mathrm{VI} / 2,7-21$.

Симић и Јовановић 2009б: Радоје Симић и Јелена Јовановић, О тексту са гледишта наратологије, Анали Филолошког факултета 21, Београд, 85-108. 
Симић 2010: Р. Симић, Стилистика српског језика. Фоностилистика, Београд: НДСЈ и Јаесн.

Симић 2017. (у шт.): Радоје Симић, Напомене о структури текста, Српски језик, ХXII.

Чомски 1984: Н. Чомски, Синтаксичке структуре, Нови Сад: Књижевна заједница Новог Сада.

\section{ON COMPOSITION FROM THE LINGUISTIC STANDPOINT}

\section{Summary}

The paper discusses the scope of linguistics in the field of composition, and the abilities of linguists to treat that topic. In our opinion, regardless of the attitude of traditional linguistics that the area of its scientific interest is limited exclusively to the sentence and its parts, linguistics is able - with its research methodology and its theoretical apparatus - to make a major contribution to understanding and explaining suprasentence (and nonsentence) phenomena in language. One of those phenomena (apart from the structural features of the text as a whole) is the composition itself.

Jelena R. Jovanović Simić 